\title{
Object of learning in the teaching of simple harmonic motion: a case study using active methodology (ISLE type)
}

\author{
Objeto de Aprendizagem (OA) no ensino do movimento harmônico simples: um estudo de caso \\ utilizando metodologia ativa (tipo ISLE)
}

Objeto de Aprendizaje (OA) en la enseñanza del movimiento armónico simple: un estudio de caso utilizando metodología activa (tipo ISLE)

Received: 09/27/2021 | Reviewed: 10/08/2021 | Accept: 10/25/2021| Published: 10/28/2021

José Carlos Ferreira Bastos

ORCID: https://orcid.org/0000-0002-1344-1548 Instituto Federal de Educação, Ciência e Tecnologia do Ceará, Brazil E-mail: jjcarlosb@ifce.edu.br Gilvandenys Leite Sales

ORCID: https://orcid.org/0000-0002-6060-2535 Instituto Federal de Educação, Ciência e Tecnologia do Ceará, Brazil E-mail: denyssales@ifce.edu.br

Jeirla Alves Monteiro

ORCID: https://orcid.org/0000-0002-9329-5930 Instituto Federal de Educação, Ciência e Tecnologia do Ceará, Brazil E-mail: jeirla@gmail.com

\begin{abstract}
In classroom, the Simple Harmonic Movement (SHM) is a content generally seen only in the form of expository classes and, for this reason, considered difficult to understand. In order to solve this problem, the following research question was asked: does the Learning Object (LO) contribute to the understanding of SHM, based on the ISLE Methodology approach? For that, simulations of SMH graphics were created with the aid of digital tools. This research was carried out at IFCE Campus Fortaleza and its main objective was to analyze the use of a LO in the discipline of Physics, aiming to assist the student in the simulation of graphs of the Simple Harmonic Movement (SHM), supported by the Active Methodology of the ISLE type, which proposes a Science Investigative Learning Environment. The students performed a pre-test in which they were to analyze and interpret the data of an SHM from its graph. Then, using the LO, the students explored the variables present in a periodic movement, being able to interact with it and visualizing the changes in the movement and in the graphs related to it. Finally, the students performed a post-test that consisted of, again, interpreting an SHM phenomenon based on its graph and producing new graphs representing other of its variables. The results point to an improvement in the understanding of the learners regarding the studied subject, indicating that the use of digital tools and active methodologies can contribute to a meaningful learning of Physics concepts, more specifically, of the SHM.
\end{abstract}

Keywords: Learning object; Active methodologies; Simple harmonic movement.

\section{Resumo}

Em sala de aula, o Movimento Harmônico Simples (MHS) é um conteúdo geralmente visto apenas na forma de aulas expositivas e, por esse motivo, considerado de difícil compreensão. Para solucionar esse problema, foi formulada a seguinte questão de pesquisa: o Objeto de Aprendizagem (OA) contribui para a compreensão do MHS, com base na abordagem da Metodologia ISLE? Para isso, foram criadas simulações de gráficos MHS com o auxílio de ferramentas digitais. Esta pesquisa foi realizada no IFCE Campus Fortaleza e teve como objetivo principal analisar a utilização de um OA na disciplina de Física, visando auxiliar o aluno na simulação de gráficos do Movimento Harmônico Simples (SHM), apoiado pelo Active Metodologia do tipo ISLE, que propõe um Ambiente de Aprendizagem Científica Investigativa. Os alunos realizaram um pré-teste no qual deveriam analisar e interpretar os dados de um MHS de seu gráfico. Em seguida, utilizando o $\mathrm{OA}$, os alunos exploraram as variáveis presentes em um movimento periódico, podendo interagir com ele e visualizar as mudanças no movimento e nos gráficos a ele relacionados. Por fim, os alunos realizaram um pós-teste que consistiu, novamente, em interpretar um fenômeno MHS a partir de seu gráfico e produzir novos gráficos representando outras de suas variáveis. Os resultados apontam para uma melhora no entendimento dos alunos sobre o assunto estudado, indicando que o uso de ferramentas digitais e metodologias ativas pode contribuir para uma aprendizagem significativa dos conceitos de Física, mais especificamente, do MHS.

Palavras-chave: Objeto de aprendizagem; Metodologias ativas; Movimento harmônico. 


\section{Resumen}

En el aula, el Movimiento Armónico Simple (SHM) es un contenido generalmente visto solo en forma de clases expositivas y, por esta razón, se considera de difícil comprensión. Para resolver este problema, se planteó la siguiente pregunta de investigación: ¿Contribuye el Objeto de Aprendizaje (OA) a la comprensión de SHM, basado en el enfoque de la Metodología ISLE? Para eso, se crearon simulaciones de gráficos SMH con la ayuda de herramientas digitales. Esta investigación se llevó a cabo en IFCE Campus Fortaleza y su objetivo principal fue analizar el uso de un LO en la disciplina de la Física, con el objetivo de ayudar al estudiante en la simulación de gráficos del Movimiento Armónico Simple (SHM), apoyado por el Activo. Metodología del tipo ISLE, que propone un Ambiente de Aprendizaje Investigativo Científico. Los alumnos realizaron un pre-test en el que debían analizar e interpretar los datos de un SHM a partir de su gráfica. Luego, utilizando el LO, los alumnos exploraron las variables presentes en un movimiento periódico, pudiendo interactuar con él y visualizando los cambios en el movimiento y en las gráficas relacionadas con él. Finalmente, los estudiantes realizaron un post-test que consistió, nuevamente, en interpretar un fenómeno de SHM a partir de su gráfica y producir nuevas gráficas que representen otras de sus variables. Los resultados apuntan a una mejora en la comprensión de los educandos con respecto al tema estudiado, indicando que el uso de herramientas digitales y metodologías activas puede contribuir a un aprendizaje significativo de los conceptos de Física, más específicamente, del SHM.

Palabras clave: Objeto de aprendizaje; Metodologías activas; Movimiento armónico.

\section{Introduction}

Traditional education, using only "blackboard and chalk" is still widespread in schools in Brazil. This type of pedagogical practice proves to be ineffective in engaging students in the activities carried out, causing mechanized learning to occur and detached from the context in which the student finds himself (Silva; Sales; Castro, 2018).

In addition, placing the teacher as the protagonist of the educational process, imposing a series of repetitive activities on students, prioritizes only the memorization of the contents addressed by the students. Thus, the formation of critical thinking by students is inhibited (Libânio, 1994).

These obstacles are quite present in the learning of Physics because students are generally not interested in the subject and the methodologies used in classes often disregard particularities and experiences brought by students, moving them away from the discipline (Lima; Gaio, 2009).

Several teaching-learning strategies that bring the student to a leading position in the learning process have been developed in recent decades. Peer Instruction (Mazur, 1997), Just-in-time Teaching (NOVAK et al., 1999), SCALE-UP (Beichner et al., 2007) and Team-Based Learning (Michaelsen; Sweet, 2011) are some of the methodologies that can change the focus of classroom activities.

SHM is a topic present in several branches of physics and engineering. It is common for students to find SHM a difficult subject to understand. This can be attributed to the excessive focus given to mathematical demonstrations, to the detriment of physical analysis of phenomena (Roche, 2002).

A way to circumvent these obstacles to teaching SHM and generate an evolution of the concepts brought by students can be found in the studies by Ausubel (1968) and in his Meaningful Learning (ML). ML takes into account what learners already know, favors the use of techniques and tools that relate to the subject studied and that are capable of arousing students' interest.

The Simple Harmonic Movement (SHM) is a content usually seen in the form of lectures only. Due to its degree of abstraction, the discipline is often considered difficult to understand. In order to reduce this problem, we sought to make simulations of SHM graphics with the aid of digital tools.

It should be noted that the Common National Curriculum Base (CNCB) establishes a series of skills that must be developed by students in basic education. With regard to Natural Sciences, high school students are expected to be able to analyze, use and interpret natural phenomena and technological processes, taking into account their impacts on the dynamics of life on Earth (Brasil, 2018). 
In addition, the CNCB proposes that the teaching of Natural Sciences encourages students to develop critical theories about the studied phenomena, formulating discourses based on scientific theories and seeking solutions to social and environmental problems at local and global levels. Students are also expected to be able to disseminate their findings to different audiences, using Digital Information and Communication Technologies (DICT) (Brazil, 2018).

It is important that the use of methodologies that allow the visualization of the studied phenomena be present in the classroom, encouraging students to question and seek understanding of the subject. In addition, by moving away from more traditional practices, encouraging students to ask questions and comments, creating and displaying the physical models created, it provides a better dynamic in the classroom (Erthal; Gaspar, 2006).

his work is anchored in the perspective of Meaningful Learning, using a didactic sequence that uses the ISLE methodology, which stands for Science Investigative Learning Environment (Etkina, 2015). The ISLE methodology seeks to encourage students to emulate the behavior of scientists, relating to the phenomena studied in order to discover and formulate their own hypotheses. In addition to being a methodology that favors the use of digital tools and has elements that dialogue with Meaningful Learning. Thus, the main objective is to analyze the use of a didactic sequence based on the ISLE Methodology in the discipline of Physics, aiming to assist the student in understanding the physical phenomena involved in Simple Harmonic Motion (SHM).

\section{Meaningful Learning}

Meaningful Learning (ML) "is the process through which new information (new knowledge) is related in a nonarbitrary and substantive (non-literal) way to the learner's cognitive structure" (Moreira, 2011, p. 22). Thus, it is believed that the use of an active learning methodology can favor the occurrence of a significant learning of the studied subject.

ML is based on the idea that new knowledge is better assimilated when built on previous ideas, called subsumers. In this process, new knowledge acquires meaning for the subject and prior knowledge acquires new meanings or greater cognitive stability. (Moreira, 2010).

The occurrence of ML occurs through the presence of three primary factors, the student's prior knowledge, the use of potentially significant materials and the student's willingness to learn (Ausubel, 1968). Methodological tools and practices can be implemented to explore each of these pillars. Such as the use of Learning Objects (LO) that present the content in an attractive way to students and exploratory tests that can indicate to the teacher the concepts present in the students' conceptual ecosystem. In addition, the very use of these resources configures the presence of potentially significant materials (Silva, 2018).

Vieira and Vieira (2003) reinforce this process by stating that one of the challenges of teaching is to make the student critical and attentive to the phenomena and techniques of their daily lives. Therefore, it can be said that digital technological resources, configuring LO, are important instruments that enrich the way students think and reflect critically in the context of physics contents, which have the opportunity to make the relationship of the theory with practice, as autonomous subjects of their own learning.

Thus, a way to promote a pedagogical environment in which the student can actively engage in the apprehension of new concepts and skills is the use of Active Learning Methodologies. Furthermore, the use of digital resources in pedagogical processes can bring new possibilities to teachers and learners, facilitating the occurrence of ML. In the next sections, the use of these resources is analyzed. 


\subsection{Actives Metodologies}

According to Prince (2004), Active Learning Methodologies (ALM) is configured in a set of actions and techniques that lead students to engage in procedures in which meaningful learning takes place. Ausubel ressalta que nos ambientes formais de estudo costuma-se priorizar a aprendizagem passiva. So that students do not have an active participation in the construction of knowledge. In this sense, it emphasizes that "students acquire a large part of their knowledge primarily through receptive learning" (Ausubel; Novak; Hanesian, 1980, p. 9).

Authors such as Wilsek and Tosin (2010) consider that the class is no longer expository, with the simple transmission of content when it starts to teach Science through the use of an active method. This means that one must innovate and shift the focus from teaching to learning. Thus, active methodologies aim at learning in which it is important to present to the student problem-situations or puzzles that instigate the development of the primordial cognitve skills in the knowledge areas.

For authors such as Borges and Alencar (2014), the ALM stimulate critical thinking. Mazur (2015) also reinforces this understanding, stating that by adopting a teaching model supported by active methodologies, the teacher assumes another posture to teach and, consequently, the educational or educational process changes and the teacher is no longer the only holder of knowledge, assuming the role of learning facilitator. It should be noted that active methodologies can establish correlations with different theories, in order to favor the acquisition of knowledge. Therefore, Behar (2009) emphasizes that they seek to use experiences and simulations to reproduce phenomena, in order to solve the challenges present in everyday activities.

It is possible to observe the use of different types of ALM being applied to different educational contexts. However, it cannot be said that a certain methodology is applicable only to certain situations and fields of knowledge, only being better adaptable to different practices. Among the most commonly applied to the teaching of Physics, it is possible to highlight Tailored Teaching, Peer Instruction and Investigation-Based Learning.

Inquiry-Based Learning (IBL), or Inquiry-Based Learning, is characterized by being a learning methodology that aims to encourage students' autonomy, making them investigative subjects. In this case, the teacher suggests an initial questioning and the students, individually or in groups, start to analyze the questions regarding the problem presented (Bruner, 1961).

According to Duarte (2012), students, when analyzing the situations proposed in the questionnaire, face difficulties when confronting physical phenomena with the mathematical models that represent them. However, when asked to carry out simple experiments, students find it easier to demonstrate an immediate recognition of the results.

The IBL is widely used together with the Digital Technologies of Information and Communication (DTIC), in the teaching of science. According to the authors mentioned above, the use of digital resources linked to the ABI can promote the overcoming of obstacles associated with the teaching area that are related to science; engaging students in the learning process and contextualizing the contents studied (Ramos; Giannella; Struchiner, 2010).

The methodology chosen to guide this study is the "Investigative Science Learning Environment" (ISLE), which was developed by a working group led by Eugenia Etkina, from Rutgers University, in the United States. Vick (2018) highlights ISLE's investigative character, classifying it as a form of Inquiry Based Learning (IBL).

\subsubsection{Metodologia ISLE - Investigative Science Learning Environment}

The Science Investigative Learning Environment, or ISLE in English, methodology is used to assist students in creating mental models about phenomena observed in the classroom. The idea behind this methodology is to stimulate in students reflections and behaviors common to those brought by scientists during the process of elaborating new theories (Etkina et al., 2010). 
Also according to Etkina et al. (2010), although conceptually similar, ISLE presents some differences in relation to IBL. At IBL, students receive initial orientations, elaborate theories and questions about the observed phenomenon, and only then carry out experiments and collect data.

On the other hand, at ISLE, students initially do not make hypotheses or explanations for the observed experiments, they only collect data and look for patterns in the information gathered. The experiments chosen for the application of this methodology must be easy to explain or show data that present well-defined patterns. In general, ISLE tends to present freer activities, where students have greater autonomy to decide which experiments will be carried out in order to analyze and collect data on the observed phenomena (Etkina et al, 2010).

ISLE proposes to take the student to learn the concepts of physics following the same steps that scientists use in the construction process and in the way of applying knowledge. In this process, the method involves: "observing, finding patterns, building and testing explanations for the patterns and using multiple representations to think about the physical phenomenon." (Parreira, 2017, p.2).

ISLE involves students in the construction of collaborative knowledge to acculturate them in scientific practice. The purpose of the environment is not only to help students learn the concepts and laws of physics, but more importantly to help them learn how this knowledge is constructed (Etkina et al, 2010). The ISLE cycle is a mixture of the Karplus learning cycle (1977) and Lawson's (2002) science cycles.

Karplus' (1977) learning cycle consists of three instructional phases that combine experiences in social transmission and encourage autonomy. These three phases are exploration, concept introduction, and concept application.

Figure 1 - Karplus Learning Cycle.

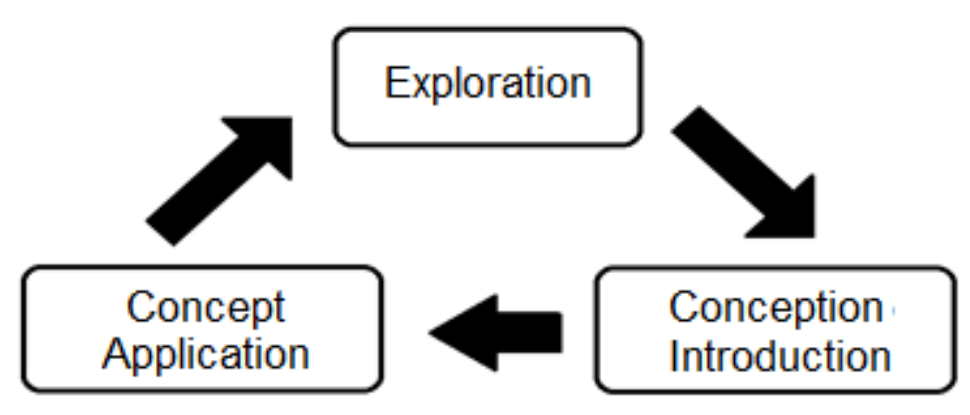

Source: Authors.

In the first phase of exploration, students are introduced to a new situation and learn from their own actions and reactions to it. At this stage they explore new materials and new ideas with minimal guidance and are not expected to achieve a pre-determined goal. In the second phase, introduction of the concept, social transmission takes place, where students receive the definition of a new concept that helps them deal with the initial experiences. During the third phase of the learning cycle, application of the concept, students become familiar with the new idea by applying it to additional situations.

Later, Lawson (2002) brought changes to the cycle, defining actions expected from both teachers and students. For Lawson these actions can be summarized as engaging, exploring, explaining, elaborating and evaluating. Participants, educators and learners, carry out these activities in contexts appropriate to their roles. In this case, teachers are guides in the learning process, creating situations that allow students to create their new knowledge.

For Planinšič and Etkina (2015) ISLE is an educational framework that can guide the way students learn. This methodology increases student participation using processes similar to scientific practices, helping them to learn Physics. In 
addition, the use of an ISLE methodology in Physics classes promoted an increase in students' understanding of the concepts present in Harmonic Movement (Rajibussalim; Rahmayani; Irwandi, 2018).

\subsubsection{Learning objects}

Learning objects (LO) can be seen as components or units, cataloged and made available in repositories on the internet. Thus, they can be used in different learning contexts, according to the instructional project. "(...) When well used, LOs can be great allies in the educational process". (Braga, 2015, p. 12). However, it is noteworthy that to promote good use of digital tools in the classroom, prior planning is necessary, which allows the educator to integrate the skills of the resources used with the knowledge that is intended to be transmitted (Moran; Masetto; Behrens, 2006).

We can also bring Polsani (2003), who conceptually defines learning objects as resources that must clearly establish the principles of their creation, that is, learning and the ability to reuse which, according to the author, are two fundamental predicates of LO. However, he also expresses his conception of learning objects as being "an independent and autonomous unit of learning contents that is predisposed to reuse in various teaching contexts" (Polsani, 2003, p.2).

\section{Methodological Development}

The research is of a quali-quantitative nature, constituting a case study. For Yin (2015), a case study is characterized by the empirical observation of a phenomenon, observed in its context and in depth.

The investigated subjects are part of a class of 19 high school students, from the sixth period of the Telecommunications Technical Course, with 01 16-year-old student, 9 17-year-old students and 09 18-year-old students.

The intervention used a didactic sequence that uses elements present in Inquiry Based Learning (IBL), allowing students to interact with the studied phenomena and develop their own theories. In addition, the ISLE methodology was used, where students were able to explore the Learning Object (LO) performing actions to measure the variables and predict the behavior of a periodic movement.

The survey was organized into four meetings, with each meeting consisting of two 50-minute lessons. Before the beginning of the activities, in the first meeting, the students answered a pre-test to assess their previous knowledge, with an emphasis on the concepts involved in the study of Simple Harmonic Movement (SHM), and the stages of carrying out the activities were detailed.

The case study took place over 4 meetings of 2 hours/class, each meeting. At the first meeting, held on March 5, a questionnaire with open questions about conceptual knowledge related to the SHM subject was applied in the classroom to assess the level of prior knowledge they brought about the subject. In the second meeting, on 10/03, the students answered a pre-test, in the classroom, in order to verify if they know how to make MHS charts, based on data provided by the teacher (researcher). Then, they went to the Laboratory of Computing Applied to Education (LCAE), to use the OA that was implemented in the free GeoGebra software. Students performed simulations of the graphics that were drawn on the SHM. In the third meeting, on 12/03, the post-test was applied, in the classroom, to see the results after using the OA. In the fourth and last meeting, on 03/16, a satisfaction questionnaire was applied in the classroom, with open questions, with the purpose of obtaining results that allow inferring whether the use of the LO facilitated or not the understanding of the content and, in what aspect the computational tool influenced the learning of the SHM graphics. This content had already been studied in the classroom, in an expository way. Each instrument took about 1 hour and 30 minutes, at most, to respond and the use of the LO took about 1 hour and 45 minutes. The pre-test questions can be seen in Table 1 below. 
Table 1 - Pre-Test Questions.

\begin{tabular}{|l|l|}
\hline .01 & What is simple harmonic motion? \\
\hline 02 & What is the amplitude of simple harmonic motion? \\
\hline 03 & Explain the duration of an oscillation. \\
\hline 04 & What is the frequency of a simple harmonic motion? \\
\hline 06 & What happens to the frequency and period when the speed of an object on the SHM increases. \\
\hline 07 & What does the period of a simple pendulum depend on? \\
\hline 08 & Explain the balancing of velocity and acceleration at the equilibrium position of an object running the SHM. \\
\hline 09 & What are the effects of wind on a swinging pendulum? \\
\hline 10 & What are the effects of a large displacement on a swinging pendulum? \\
\hline
\end{tabular}

Source: Adapted from Madu (2012).

In the second meeting, a pre-test was applied, addressing the students' skills regarding the construction of SHM charts, through their knowledge of the variables needed to design the elongation chart. Also on that occasion, the students were taken to the Laboratory of Computing Applied to Education (LCAE), where they could explore the GeoGebra software, developing simulations and graphics in preparation for the following activities.

The application, built with the GeoGebra tool, chosen to carry out this research was Potential Energy of a Spring. This Learning Object (OL) allows students to observe the drawing of graphics related to the oscillatory motion of a spring mass assembly. It is possible to change the values assigned to the elastic constant of the spring, the block mass and the initial elongation of the set. In addition, the OL shows variations in the values of acceleration, velocity, displacement, potential energy and kinetic energy of the system, based on initial information given by the students. It is possible to stop the animation at any time so that the teacher can analyze the different phases of the movement with the students. Figure 2 shows an LO screen where its functionalities can be seen. 
Figure 2 - Initial screen of LO Potential Energy of a Spring.

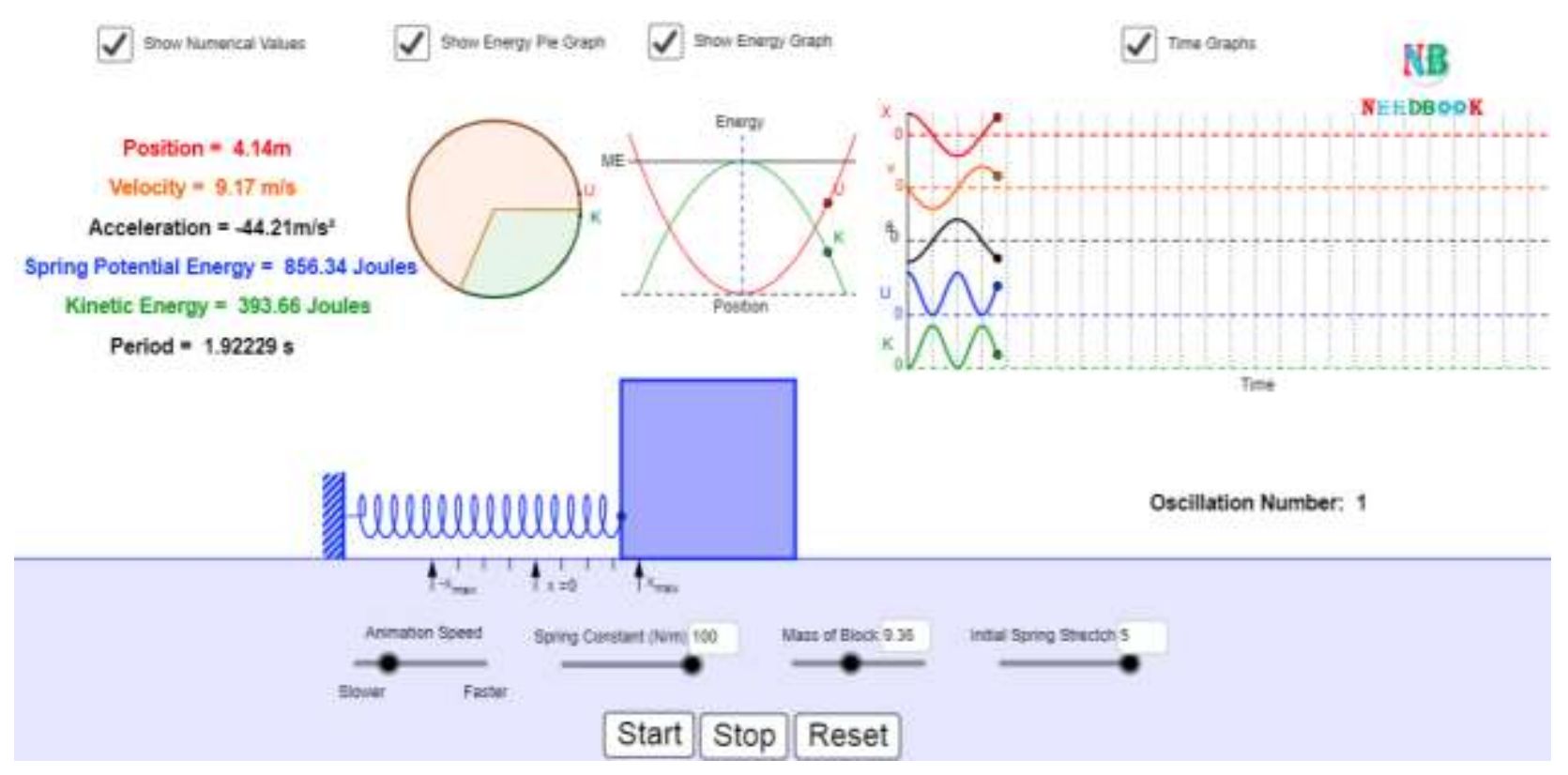

Source: Authors.

In the third class, as a form of post-test, an activity was carried out in which we sought to analyze the students' abilities regarding the elaboration of SHM charts. It was intended to investigate whether there was an increase in students' understanding of the concepts necessary for the correct graphical representation of the equations.

At the end of the cycle of activities, a satisfaction questionnaire was carried out on the students' opinion about the pedagogical practices used during the meetings.

\section{Data Analysis}

To organize the activities and enable a better evaluation of the results obtained, a pre-test was carried out. The questions aimed to establish the level of the students' prior knowledge, with questions that addressed theoretical and conceptual aspects of the Simple Harmonic Motion.

In addition to bringing an overview of the subsumers brought by the students, the analysis of the students' responses helped to identify possible difficulties in understanding them about the SHM. With this information, the teacher can better prepare their lesson plans and define the approach to the themes to be explored. The data collected during this pre-test are compiled in Table 2 . 
Table 2 - Pre-Test Prior Knowledge.

\begin{tabular}{|c|c|c|c|}
\cline { 2 - 4 } & Hit (\%) & $\begin{array}{c}\text { Partial } \\
\text { hit (\%) }\end{array}$ & Error (\%) \\
\hline Question 1 & 42,1 & 36,8 & 21,1 \\
\hline Question 2 & 31,6 & 31,6 & 36,8 \\
\hline Question 3 & 57,9 & 21,1 & 21,1 \\
\hline Question 4 & 47,4 & 31,6 & 21,1 \\
\hline Question 5 & 36,8 & 47,4 & 15,8 \\
\hline Question 6 & 68,4 & 31,6 & 0,0 \\
\hline Question 7 & 84,2 & 10,5 & 5,3 \\
\hline Question 8 & 73,7 & 15,8 & 10,5 \\
\hline Question 9 & 42,1 & 52,6 & 5,3 \\
\hline Question 10 & 68,4 & 21,1 & 10,5 \\
\hline
\end{tabular}

Source: Authors.

Table 2 shows the percentages of correct answers, partial correct answers and students' errors in each question presented in the pre-test. Students' answers that, despite being incomplete, indicate a certain level of knowledge about the topic are considered partial correct answers. The results indicate that many of the students demonstrate difficulties in dealing with the concept of amplitude in the SHM. Only 31.6\% of the students answered Question 2 completely, with the same number of partial correct answers. While $36.8 \%$ of respondents did not provide satisfactory answers to the question.

On the other hand, $84.2 \%$ of students were able to correctly describe the correlation between position and kinetic energy in a body that describes a pendulum movement. Furthermore, $73.7 \%$ of students were able to explain the relationship between velocity and acceleration of a body that describes an SHM as it passes through its equilibrium position.

Thus, it is possible to affirm that the class had a medium level global knowledge about the SHM. The students were able to elaborate answers that, despite not being completely correct, most of them satisfactorily described questions about the conceptual aspects of the Simple Harmonic Motion.

\subsection{Hourly Functions and Graph Construction}

Tests were performed before and after using the LO, in order to investigate possible developments in the way students relate to the contents of the SHM. In the tests, students were asked to analyze a graph of a periodic movement and based on the information acquired based on its interpretation, describe the equations that govern this movement. In addition, students should generate graphs that represent other parameters of this same phenomenon.

During the pre-test, students should correctly write the hourly functions of velocity and acceleration of movement described in the elongation graph. The objective of this stage of the study was to determine the students' ability to remember, understand and apply the different ways of mathematically describing the SHM, extracting information from the graph presented. After carrying out the activities using the OL, the students were again tested, and the results compared.

It is possible to notice that during the pre-test $60 \%$ of the students already demonstrated an average level in their ability to interpret the graphs. In addition, less than $25 \%$ of the class was not able to correctly write any of the equations requested. This, together with the information collected during the conceptual pretest, demonstrates that the students already had an intermediate understanding of the SHM.

The analysis of the post-test results indicates that after using the LO, there was an improvement in the students' ability to extract and interpret the references from the graphs. There was a $31.58 \%$ improvement in the number of students who were able to write the two equations requested correctly. In addition, the number of students who answered incompletely or not at 
this stage of the test decreased by $15.79 \%$ in both cases. The results found corroborate the studies by Amrani and Paradis (2010), who claim that students performing computer-based laboratory activities show an improvement in their understanding of physical phenomena. The results of this stage of the research are shown in Figure 3.

Figure 3 - Pre-Test vs. Post-Test Graph on the SHM Equations.

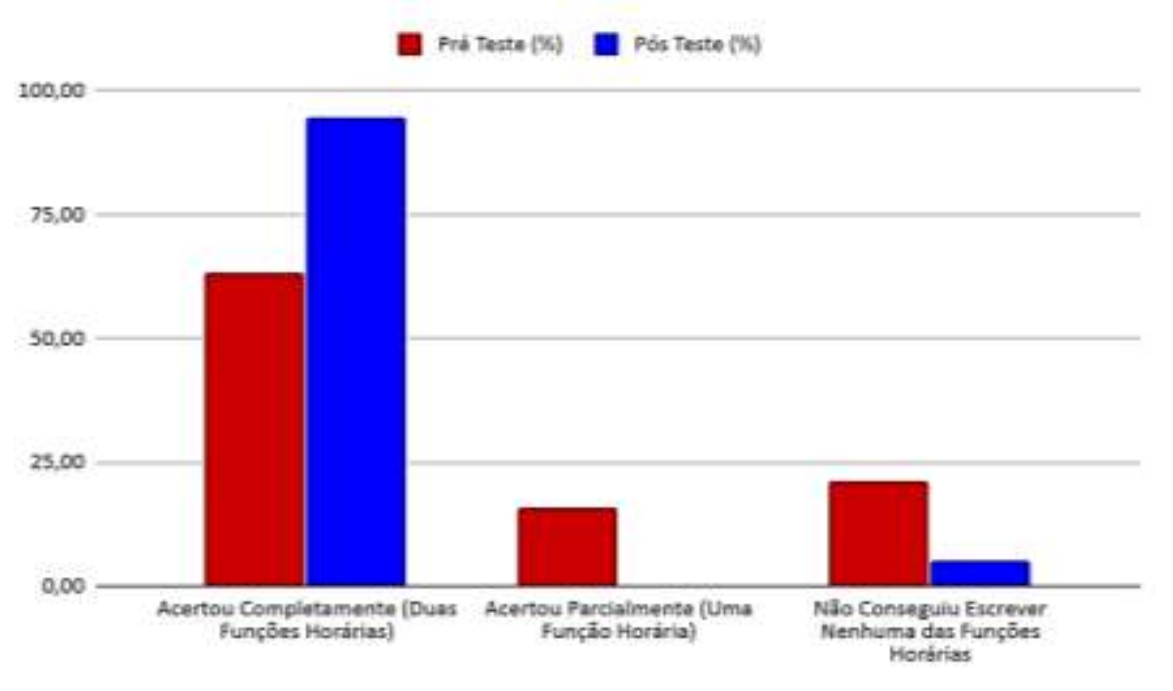

Source: Authors.

As for the ability of students to build graphs related to a periodic movement based on the interpretation of an initial graph, it was found that there was an improvement after using the LO. There was a $26.32 \%$ increase in the number of students who were able to correctly draw the graphs of velocity and acceleration of motion described in the elongation graph that was presented to them. Furthermore, there was a $31.58 \%$ decrease in the number of students who were unable to build any of the requested graphics. The use of LO allowed to overcome some of the difficulties faced by students in understanding the SHM, such as lack of motivation, deficiencies in understanding numerical expressions and alternative conceptions brought from other topics in Physics (Aykutlu; Bezen; Bayrak, 2015).

Although the absolute numbers indicate only an average performance, the comparison between the results of the pretest and the post-test point to an improvement in the understanding of the concepts related to MHS by the students. The results obtained corroborate the findings of Demaree and Lin (2006), who came to the conclusion that students inserted in an ISLE environment develop a better understanding of the concepts and are better able to communicate their ideas. The results referring to the analysis of the production of graphs by the students are compiled in the form of a graph that can be seen in Figure 4. 
Figure 4 - Pre-Test vs. Post-Test Graph on MHS Graph Construction.

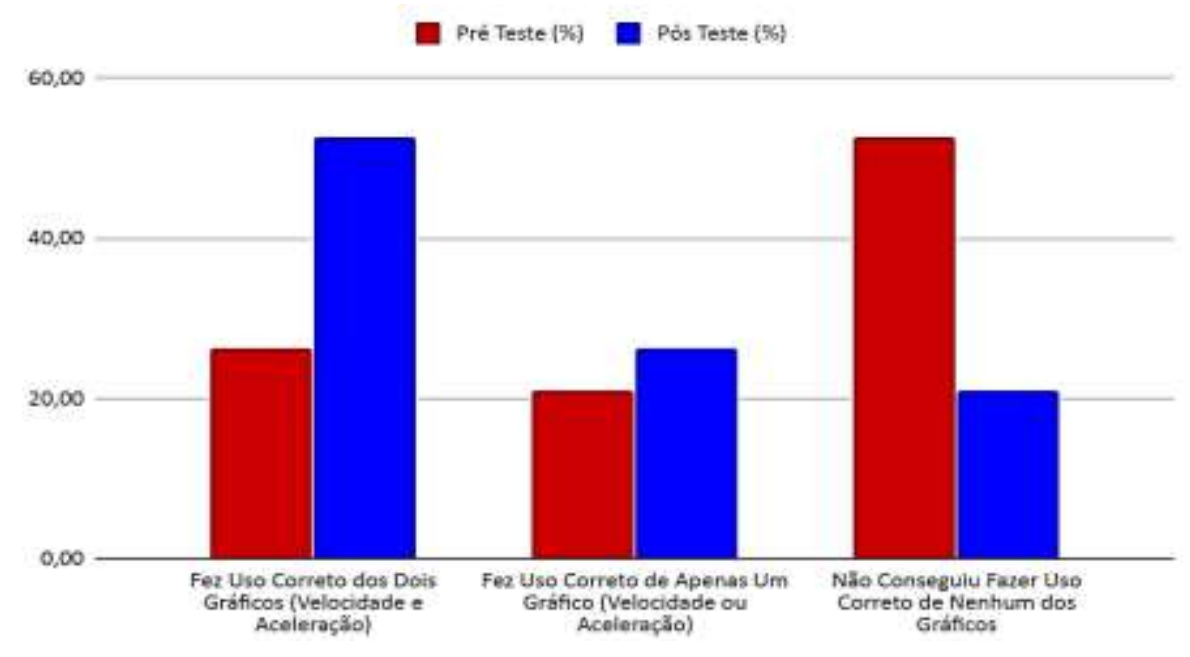

Source: Authors.

Analyzing the global scores of the activities performed, the non-parametric Wilcoxon test was applied to verify whether there were significant changes in the results of the group of students, when writing the hourly functions of velocity and acceleration, and when preparing the SHM graphs (Simple Harmonic Motion), before and after using the learning object with the tool implemented with GeoGebra.

According to the level of p-significance found, it is possible to confirm with $99.9 \%$ confidence that there was a change between the pre-test and the post-test, when using LO (Learning Object). The confirmation of the change took place soon after the application of the T-Student parametric statistical test, which was compared if there was a significant change, between the average scores of the two groups, and with the same reliability of $99.9 \%$, the change was confirmed with a high rate of evolution of the grades. The graph showing the comparison between the scores before and after using the LO is shown in Figure 5 below.

Figure 5 - Global Notes Graph Before and After LO Usage.

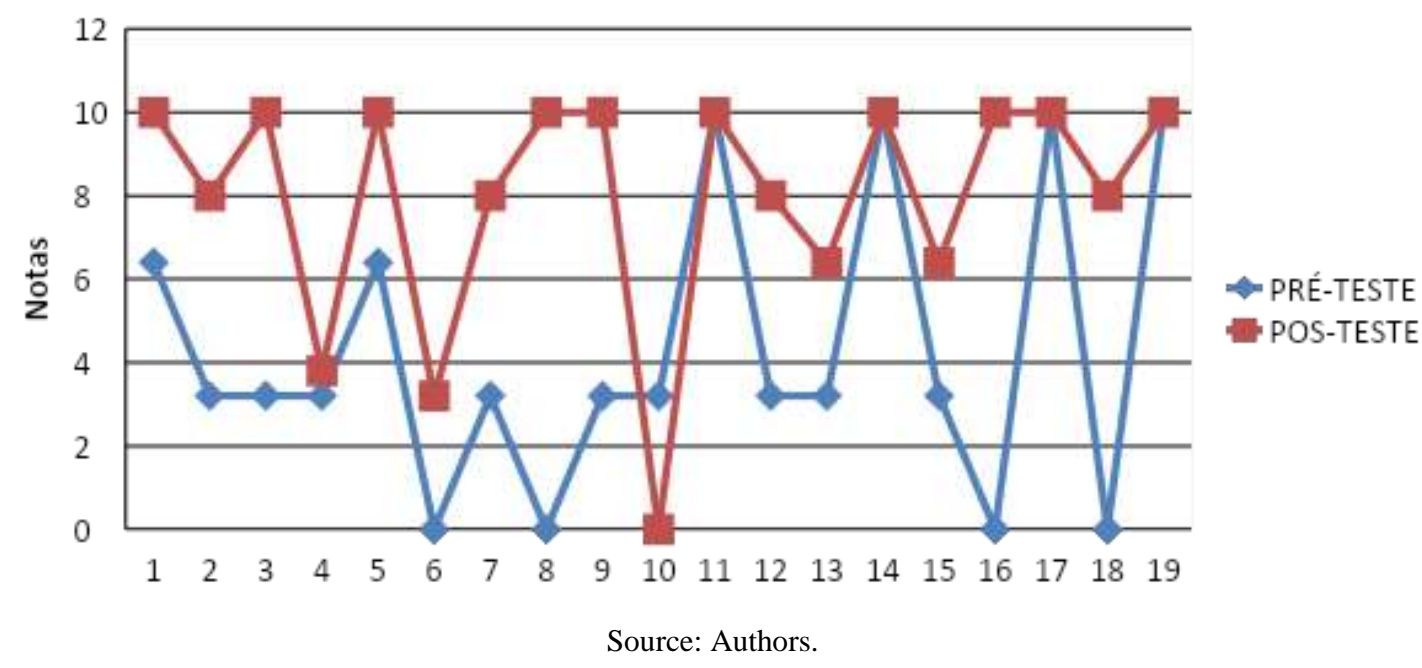

The analysis and interpretation of statistical data and the treatment of information were based and calculated using the SPSS - Statistics system. (22.0) in online mode using the internet. 


\subsection{Student Opinions on Activities and Tools}

At the end of the research, a questionnaire was applied in order to determine the students' opinions about the activities carried out and the tools used. The questions asked are compiled in Table 3.

Table 3 - Satisfaction Questionnaire.

\begin{tabular}{|c|}
\hline Qatisfaction Questionnaire \\
\hline Q.1 What concept would you attribute to the laboratory environment (LCAE) used by you in the use of the LO. \\
\hline Q.2 And with regard to computers. \\
\hline Q.3 Regarding Internet velocity. \\
\hline Q.4 The preliminary explanation given by the professor on the subject under study (SHM). \\
\hline Q.5 Your interest in the conceptual part. \\
\hline Q.6 Your interest in the practical part. \\
\hline Q.7 Degree of ease of use of the LO. \\
\hline Q.8 Degree of interest in using LO. \\
\hline Q.9 Ease of understanding level of LO usage. \\
\hline Q.11 As for the layout of the graphics in LO. \\
\hline Q.12 Degree of help in learning how to make graphics. \\
\hline Q.13 Level of help in the elaboration of the speed graph. \\
\hline Q.14 Help level in the elaboration of the acceleration graph. \\
\hline Q.15 Helped in completing the post-test. \\
\hline
\end{tabular}

Source: Authors.

The questions address the students' view of different aspects of research, with questions Q.1, Q.2 and Q.3 dealing with the physical structure and conditions for conducting the study. Questions Q.4, Q.5 and Q.6 refer to the theoretical part and the students' motivation on the subject of the classes. Questions Q.7, Q.8, Q.9, Q.10 and Q.11 refer to how students understand certain aspects of the LO used. Finally, questions Q.12, Q.13, Q.14 and Q.15 seek to collect information about the influence of LO perceived by students in carrying out the requested activities.

Students responded positively to most of the questions asked. As for the structure and resources of the laboratory where the research took place, $68.4 \%$ of the students considered the organization of the environment as excellent or good.

Regarding the computers used in the laboratory, $63.2 \%$ of the students expressed positive opinions (excellent or good), while $26.3 \%$ attributed to them the "regular" concept.

Opinions were more diverse with regard to the internet speed used. Of the 19 students interviewed, $42.1 \%$ attributed the concept "good", $36.8 \%$ considered the speed "regular", while the opinions "excellent" and "insufficient" corresponded to $5.3 \%$ of the answers. A graph with the answers given by the students can be seen in Figure 6. 
Figure 6 - Physical Structure and Laboratory Conditions.

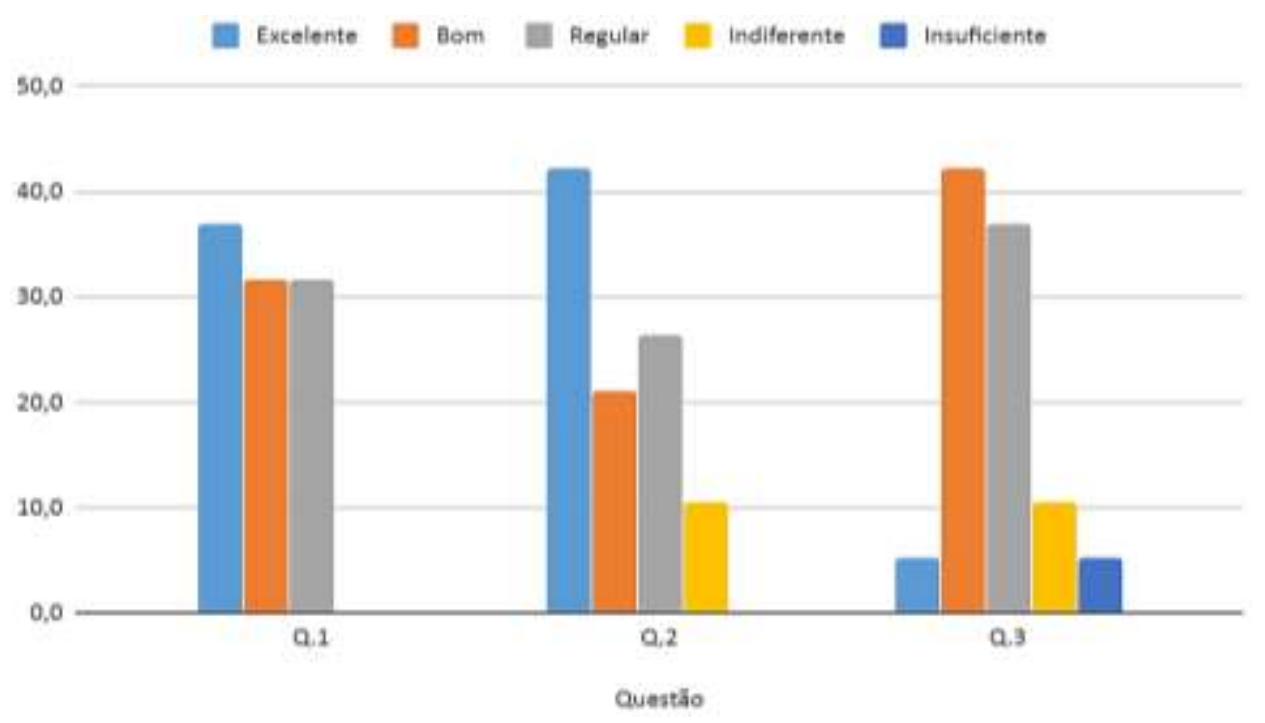

Source: Authors.

It is possible to notice, from the students' answers, that the structure offered by the institution to carry out the work was satisfactory. In fact, the resources present in LCAE surpass those normally found in most public schools. However, it is possible to believe that the same practice could be performed in a simpler computer lab, without prejudice to the activities.

The next sequence of questions addresses the students' interest in the subject covered in the research, as well as the teacher's role in theoretical classes. Of the interviewees, $73.7 \%$ stated that the preliminary explanation about SHM was satisfactory, with $57.9 \%$ of the students attributing the grade "good" and $15.8 \%$ the grade "excellent". Regarding the students' interest in simple harmonic movement, $21.1 \%$ attributed the maximum concept to the conceptual facet of the subject. Meanwhile, $47.4 \%$ showed more interest in the practical part of the SHM. Thus, it is possible to note that the use of experiments is capable of generating greater engagement on the part of students in relation to the study of SHM. The data collected at this stage of the research are shown in Figure 7.

Figure 7 - Theoretical Classes and Student Motivation.

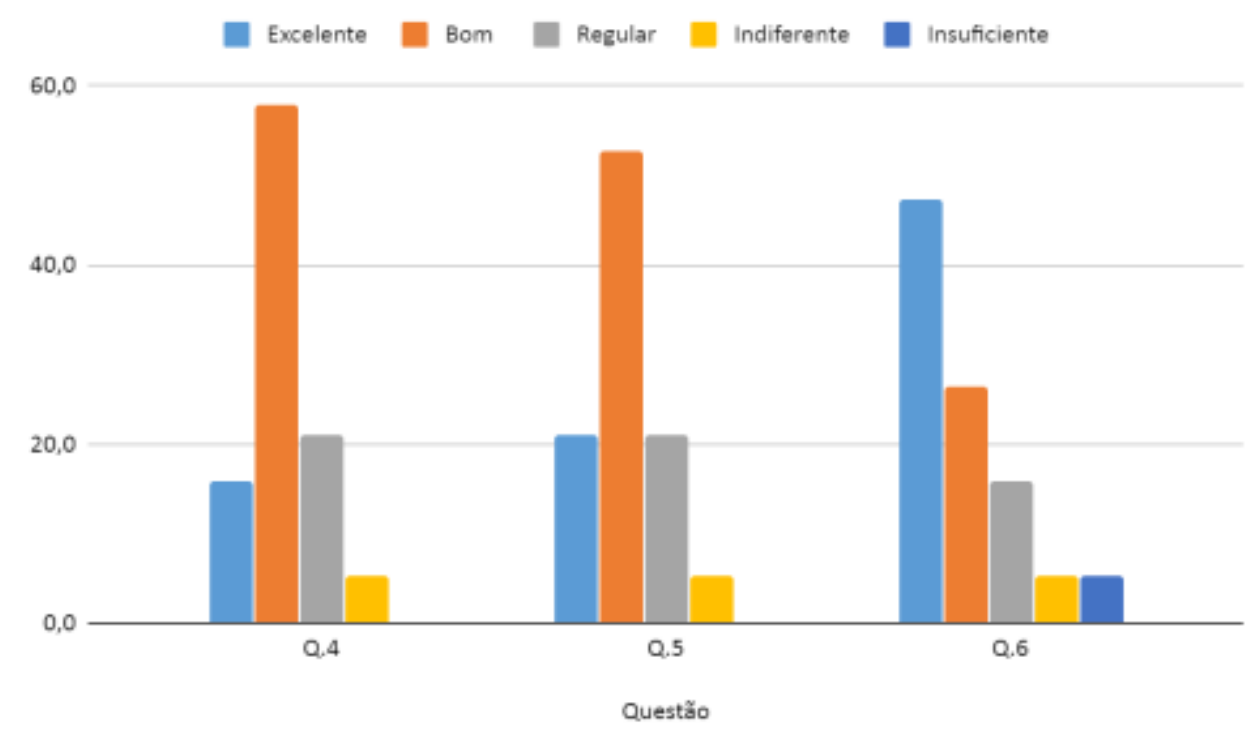


About the students' opinions about the LO properties, the analysis indicates that, in general, the students considered the use of the resource positive. As for the ease of use of the LO, 36.8\% of respondents considered it excellent and $42.1 \%$ considered it good. Regarding the students' interest in the learning object, $52.6 \%$ attributed the highest possible concept, while $42.1 \%$ attributed the level of ease in understanding the LO as "excellent".

The graphics layout in the LO got $42.1 \%$ of "excellent" responses. In addition, $63.2 \%$ of respondents considered that the level of help from the AB in understanding the MHS charts was "excellent".

Thus, the responses indicate that the use of an LO for teaching SHM, in addition to arousing greater interest from students, offers new ways to approach the subject. Furthermore, it contributes to the understanding of the graphics explored during the activities performed. The answers for this stage of the questionnaire are shown in Figure 8.

Figure 8 - Learning Object Usage and Characteristics.
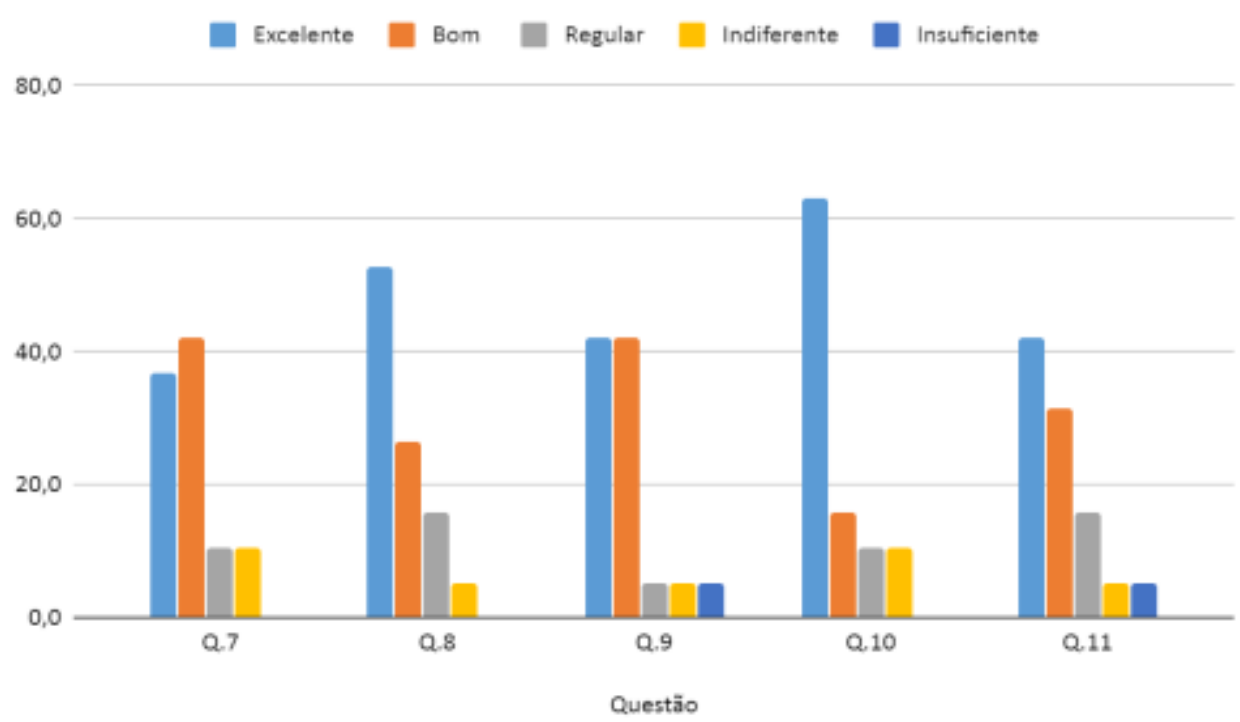

Source: Authors.

As for the influence of the learning object in the execution of activities, the average of positive responses was even higher than in the other sections. $57.9 \%$ of the students attributed maximum grade to the degree of help that the LO provided in learning the graphics. Still, specifically about the elaboration of the velocity graph, $52.6 \%$ of the students said that the OA was excellent. And about its influence on the creation of the acceleration graph, $63.2 \%$ of respondents considered it excellent.

Amrani and Paradis (2010) emphasize the interest of students when interacting with digital tools that allow automatic feedback of the created graphics. This type of tool allows students to more efficiently understand the variables involved in the MHS and their representations.

The highest positive value obtained in the questionnaire came in the last question, which addressed the help that the OA provided to carry out the post-test. $78.9 \%$ of students attributed maximum concept to the influence of the learning object. The results indicate similarities with what was found by Parnafes (2010), by demonstrating that by being able to significantly interact with a simulated phenomenon, students are able to better analyze these phenomena in the real world. The percentages of each answer are shown in Figure 9. 
Figure 9 - Influence of the LO in the Performance of Activities.

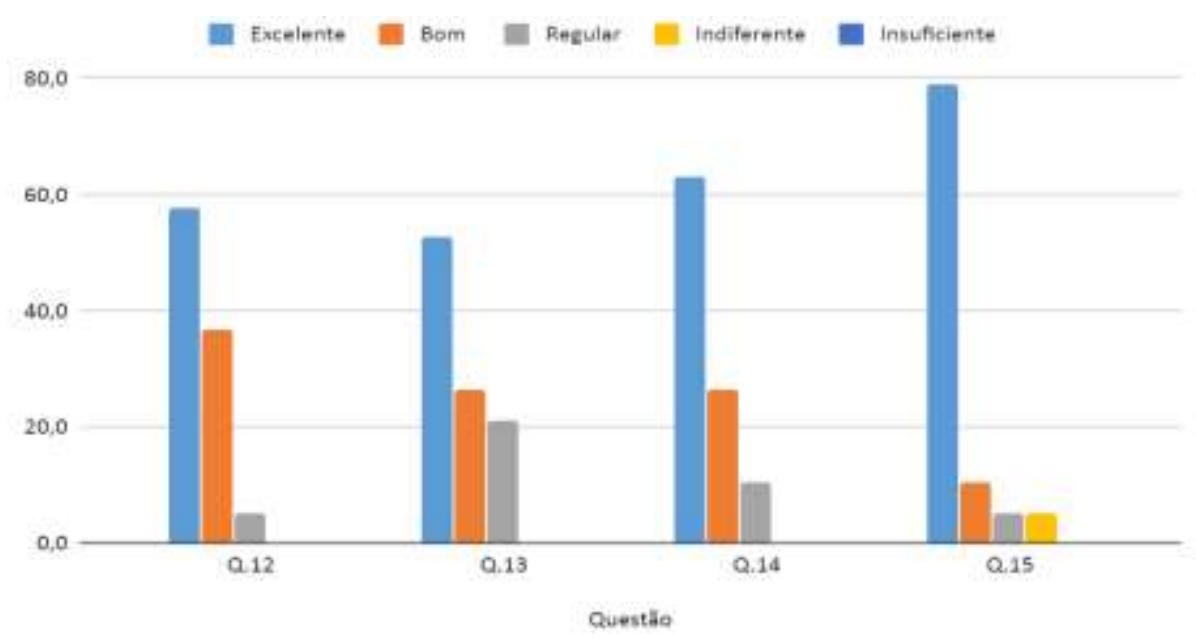

Source: Authors.

It is possible to notice by the value of positive answers that most students consider that the use of the LO had a favorable influence on the learning of the MHS. Furthermore, the increase in students' motivation when performing practical activities in the study of Physics is evident. These answers are in line with what was found by Silva (2018) when pointing out that students see the use of digital tools as a way to promote a better understanding of the concepts studied.

Students also palpably believe that the use of the digital tools used in the research played an important role in their success. You can see the percentages of responses for each question in the questionnaire in Table 4.

Table 4 - Student Opinion Quiz Answers.

\begin{tabular}{|r|r|r|r|r|r|}
\hline $\begin{array}{l}\text { Questã } \\
\text { o }\end{array}$ & $\begin{array}{c}\text { Excellent } \\
(\%)\end{array}$ & $\begin{array}{c}\text { Goo } \\
\mathbf{d}(\boldsymbol{\eta})\end{array}$ & $\begin{array}{c}\text { Regular } \\
(\boldsymbol{\%})\end{array}$ & $\begin{array}{c}\text { Indifferent } \\
(\%)\end{array}$ & $\begin{array}{c}\text { Insufficient } \\
(\%)\end{array}$ \\
\hline $\mathbf{Q . 1}$ & 36,8 & 31,6 & 31,6 & 0,0 & 0,0 \\
\hline $\mathbf{Q . 2}$ & 42,1 & 21,1 & 26,3 & 10,5 & 0,0 \\
\hline $\mathbf{Q . 3}$ & 5,3 & 42,1 & 36,8 & 5,3 \\
\hline $\mathbf{Q . 4}$ & 15,8 & 57,9 & 21,1 & 5,3 & 0,0 \\
\hline $\mathbf{Q . 5}$ & 21,1 & 52,6 & 21,1 & 5,3 & 5,3 \\
\hline $\mathbf{Q . 6}$ & 47,4 & 26,3 & 15,8 & 10,5 & 0,0 \\
\hline $\mathbf{Q . 7}$ & 36,8 & 42,1 & 10,5 & 5,3 & 0,0 \\
\hline $\mathbf{Q . 8}$ & 52,6 & 26,3 & 15,8 & 5,3 & 5,3 \\
\hline $\mathbf{Q . 9}$ & 42,1 & 42,1 & 5,3 & 10,5 & 0,0 \\
\hline $\mathbf{Q . 1 0}$ & 63,2 & 15,8 & 10,5 & 5,3 & 5,3 \\
\hline $\mathbf{Q . 1 1}$ & 42,1 & 31,6 & 15,8 & 0,0 & 0,0 \\
\hline $\mathbf{Q . 1 2}$ & 57,9 & 36,8 & 5,3 & 0,0 & 0,0 \\
\hline $\mathbf{Q . 1 3}$ & 52,6 & 26,3 & 21,1 & 0,0 & 0,0 \\
\hline $\mathbf{Q . 1 4}$ & 63,2 & 26,3 & 10,5 & 5,3 & 0,0 \\
\hline $\mathbf{Q . 1 5}$ & 78,9 & 10,5 & 5,3 & & \\
\hline
\end{tabular}

Source: Authors.

\section{Final Considerations}

The importance of building a teaching of Physics that leads to meaningful learning is evidenced by several studies that present situations in which the student takes an active role in structuring their own knowledge. In this sense, the use of active 
learning methodologies has been more widely disseminated in school environments. Furthermore, the almost omnipresence of technology in the lives of teachers and students facilitates and encourages the use of digital tools in school activities.

The search for meaningful learning can benefit from the use of digital tools and active methodologies, as these elements can generate greater student engagement, in addition to bringing more options for students to interact with knowledge.

This work was designed to explore the influence of active methodologies, with emphasis on the use of the ISLE methodology, in teaching Simple Harmonic Movement concepts. Still, the ISLE methodology itself makes room for the use of digital tools, by proposing the creation of an investigative environment in which students can interact with the analyzed experiments and phenomena. Thus, a didactic sequence was used that could explore the potential of the tools and methodologies used, in order to provide meaningful learning.

The use of such resources was facilitated by the structure provided by the IFCE, which has a computer lab aimed at learning assisted by digital tools, LCAE, in addition to offering other means of connecting students to content, such as experiments, internet access via wi-fi, measuring equipment etc. It is possible to say that the IFCE has many resources that are not present in most public schools, however, the techniques used in this study were organized so that they can be replicated in different school contexts.

Regarding the use of a Learning Object (LO) as a resource for learning Simple Harmonic Movement (SHM), it can be observed that, in addition to indicating that the addition of an interactive digital tool generated a new stimulus to the developed activities, the students obtained better results in the test performed after the use of the LO. Such results may indicate the occurrence of a better appropriation of knowledge about the SHM graphics.

The methodology used during classes, ISLE (Investigative Science Learning Environment), leads students to behave like scientists, performing measurements, analyzing and weaving theories about the studied phenomena. In this case, students were very interested during the development of activities, demonstrating a greater involvement with the concepts presented than when compared to classes that use traditional methodologies.

Furthermore, when analyzing the graphs constructed by the students during the period in which the research took place, it was possible to observe a considerable improvement in the results regarding their interpretation and construction. Learners were able to recognize patterns and extrapolate them to find new information. This increase in levels of abstraction and mastery of SHM concepts can be attributed to working with digital tools and active methodologies, organized in a didactic sequence.

Furthermore, it is necessary to emphasize that although the teaching of Physics benefits from the inclusion of digital tools and active methodologies, not all schools have a structure that can favor the implementation of these practices. It is necessary that studies on this topic seek to present alternatives that allow the democratization of these resources. Thus, it is considered that the research was successful and presented a didactic sequence capable of engaging students and fostering a significant learning of SHM concepts.

\section{References}

Amrani, D., \& Paradis, P. (2010). Use of computer-based data acquisition to teach physics laboratories: case study-simple harmonic motion. Latin-American Journal of Physics Education, 4(3), 6.

Ausubel, D. P., Novak, J. D., \& Hanesian, H. (1976). Psicología educativa: un punto de vista cognoscitivo (Vol. 3). México: Trillas.

Aykutlu, I., Bezen, S., \& Bayrak, C. (2015). Teacher opinions about the conceptual challenges experienced in teaching physics curriculum topics. ProcediaSocial and Behavioral Sciences, 174, 390-405.

Behar, P. A. (2009). Modelos pedagógicos em educação a distância. Artmed Editora. 
Borges, T. S., \& Alencar, G. (2014). Metodologias ativas na promoção da formação crítica do estudante: o uso das metodologias ativas como recurso didático na formação crítica do estudante do ensino superior. Cairu em revista, 3(4), 119-143.

Braga, J. C. (2015). Objetos de aprendizagem, volume 2: metodologia de desenvolvimento. Santo André: Editora da UFABC.

Brasil. (2018). Base Nacional Comum Curricular: Ensino Médio. Brasília: MEC/Secretaria de Educação Básica.

Bruner, J. S. (1961). The act of discovery. Harvard educational review.

Demaree, D., \& Lin, Y. (2006, February). Assessing ISLE Labs as an Enhancement to Traditional Large-Lecture Courses at the Ohio State University. In AIP Conference Proceedings (Vol. 818, No. 1, pp. 105-108). American Institute of Physics.

Etkina, E., Karelina, A., Ruibal-Villasenor, M., Rosengrant, D., Jordan, R., \& Hmelo-Silver, C. E. (2010). Design and reflection help students develop scientific abilities: Learning in introductory physics laboratories. The Journal of the Learning Sciences, 19(1), 54-98.

Etkina, E. (2015). Millikan award lecture: Students of physics-Listeners, observers, or collaborative participants in physics scientific practices? American Association of Physics Teachers (AAPT). http://dx.doi.org/10.1119/1.4923432.

Karplus, R. (1977). Science Teaching and the Development of Reasoning. Journal of Research in Science Teaching. 14(2), 169-75.

Lawson, S. (2002). Examining the relationship between organizational culture and knowledge management. Nova southeastern university.

Lima, E. A. \& Gaio, D. C. (2009). FÍSICA: a importância da experimentação associada ao lúdico.

Lima, L. A., Alonso, K. \& Maciel, C. (2013). Análise da Qualidade em Objetos de Aprendizagem: reflexão sobre aspectos pedagógicos. In: Anais dos Workshops do Congresso Brasileiro de Informática na Educação

Mazur, E. (2015). Peer instruction: a revolução da aprendizagem ativa. Penso Editora.

Michaelsen, L. K., Sweet, M., \& Parmelee, D. X. (Eds.). (2011). Team-Based Learning: Small Group Learning's Next Big Step: New Directions for Teaching and Learning, Number 116 (Vol. 103). John Wiley \& Sons.

Moran, J. M. (2000). Novas tecnologias e mediação pedagógica. Papirus Editora.

Moreira, M. A. (2012). ¿ Al afinal, qué es aprendizaje siginificativo?. Qurriculum: revista de teoría, investigación y práctica educativa. La Laguna, Espanha. No. 25 (marzo 2012), p. 29-56.

Moreira, M. A., Caballero, M., \& Rodríguez, M. (2012). Aprendizagem significativa: um conceito subjacente. 1997. http://www. if. ufrgs. br/ moreira/apsigsubport. pdf Acesso, 2021-08-19.

Novak, G. M., Patterson, E. T., Gavrin, A. D., \& Christian, W. (1999). Just in time teaching.

Parnafes, O. (2010). When simple harmonic motion is not that simple: Managing epistemological complexity by using computer-based representations. Journal of Science Education and Technology, 19(6), 565-579.

Parreira, J. E. (2017). Aplicação e avaliação de uma metodologia de aprendizagem ativa (tipo ISLE) em aulas de Mecânica, em cursos de Engenharia. Revista Brasileira de Ensino de Física, 40. FapUNIFESP (SciELO). http://dx.doi.org/10.1590/1806-9126-rbef-2017-0180. <http://www.scielo.br/pdf/rbe f/v40n1/1806-1117-rbef-40-01-e1401.pdf>.

Planinšič, G., \& Etkina, E. (2015). Light-emitting diodes: Learning new physics. The Physics Teacher, 53(4), 210-216.http://dx.doi.org/10.1119/1.4914558.

Polsani, P. R. (2003). Use and abuse of reusable learning objects. Journal of Digital information, 3(4).

Prince, M. (2004). Does active learning work? A review of the research. Journal of engineering education, 93(3), $223-231$.

Rajibussalim, R., Rahmayani, E., \& Irwandi, I. (2018, November). Utilising Investigative Science Learning Environment (ISLE) based STEM module for enhancing students' understanding of Physics concepts. In Journal of Physics: Conference Series (Vol. 1120, No. 1, p. 012086). IOP Publishing. http://dx.doi.org/10.1088/1742-6596/1120/1/012086.

Ramos, P., Gianella, T. R., \& Struchiner, M. (2010). A pesquisa baseada em design em artigos científicos sobre o uso de ambientes de aprendizagem mediados pelas tecnologias da informação e da comunicação no ensino de ciências. Alexandria: Revista de Educação em Ciência e Tecnologia, 3(1), 77-102.

Roche, J. (2002). Introducing simple harmonic motion. Physics Education, 37(6), 497. Publishing. http://dx.doi.org/10.1088/0031-9120/37/6/306.

Silva, D. (2018). Metodologias Ativas como Subsídio para a Evolução de Conceitos de Física Moderna sob a Ótica da Aprendizagem Significativa. 96 f. Dissertação (Mestrado) - Curso de Ensino de Ciências e Matemática, Instituto Federal de Educação, Ciência e Tecnologia do Ceará, Fortaleza, 2018. http://pgecm.fortaleza.ifce.edu.br/wp-content/uploads/2019/01/FINAL-DIEGO-IFCE-Final.pdf.

Silva, D., Sales, G. L., \& de Castro, J. B. (2018). A utilização do aplicativo Plickers como ferramenta na implementação da metodologia Peer Instruction. Revista Eletrônica Científica Ensino Interdisciplinar 4(12), 502-516.

Vick, V. C. (2018). The Effect of 7E Model Inquiry-based Labs on Student Achievement in Advanced Placement Physics: An Action Research Study (Doctoral dissertation, University of South Carolina).

Marques, R. V., \& Tenreiro, C. V. (2003). A formação inicial de professores e a didáctica das ciências como contexto de utilização do questionamento orientado para a promoção de capacidades de pensamento crítico. Revista Portuguesa de Educação, 16(1), $231-252$. 
Research, Society and Development, v. 10, n. 14, e122101421137, 2021

(CC BY 4.0) | ISSN 2525-3409 | DOI: http://dx.doi.org/10.33448/rsd-v10i14.21137

Wilsek, M. A. G., \& Tosin, J. A. P. (2009). Ensinar e aprender ciências no ensino fundamental com atividades investigativas através da resolução de problemas. Portal da Educação do Estado do Paraná, 1686-8.

Yin, R. K. (2015). Estudo de Caso-: Planejamento e métodos. Bookman editora. 